\title{
Action of mouthwashes on Staphylococcus spp. isolated in the saliva of community and hospitalized individuals
}

\author{
Denise de Andrade ${ }^{1}$, Paula Regina de Souza ${ }^{1}$, Carolina Contador Beraldo ${ }^{1}$, \\ Evandro Watanabe', Mery Elen Lima ${ }^{1}$, Vanderlei José Haas ${ }^{1}$ \\ ${ }^{1}$ College of Nursing at Ribeirão Preto, University of São Paulo, \\ ${ }^{2}$ Faculty of Pharmaceutical Sciences at Ribeirão Preto, University of São Paulo
}

\begin{abstract}
The use of mouthwashes in critical patients has been a source of concern for health professionals due to the diverse range of products, causing uncertainty about which is the most indicated. This study aimed to assess the susceptibility of Staphylococcus spp. isolated in the saliva of individuals from the community and patients in Intensive Care Units (ICU) as to antiseptic mouthwashes. The following oral antiseptics were assessed: cetylpyridinium chloride solution, Listerine ${ }^{\circledR}$ and $\mathrm{Neen}^{\circledR}$. Calcium alginate swab was used for saliva collection to isolate Staphylococcus spp. Microbiological processing involved growth, isolation, strain identification and determination of MID (maximum inhibitory dilution). MID was considered the greatest dilution that completely inhibited the strains. The products efficacy was analyzed by a two-factor ANOVA repeated measures and by Bonferroni adjustments in multiple comparisons, considering a significance level of $\alpha=0.05$. In total, 80 strains of Staphylococcus spp. were isolated, 40 from ICU patients and 40 from community individuals. MID results revealed that cetylpyridinium chloride solution presented better results in comparison to other products, that is, $39(97.5 \%)$ strains from hospital patients with MID 1:128, and 37 (92.5\%) of individuals from the community had MID $1: 64$. Neen ${ }^{\circledR}$ inhibited all strains in both groups at a dilution from $1: 2$ to $1: 4$. Listerine ${ }^{\circledR}$ presented the worst MID results, $65 \%$ of the strains from individuals from the community and $10 \%$ of hospital strains were not inhibited at a dilution of 1:2.
\end{abstract}

Uniterms: Oral health. Staphylococcus spp. Mouthwashes. Oral hygiene.

O uso de antissépticos bucais tem sido uma das preocupações dos profissionais de saúde considerando a diversidade de produtos, o que traz a insegurança sobre qual é o mais adequado. Objetivou-se avaliar a suscetibilidade de Staphylococcus spp. isolado da saliva de indivíduos adultos da comunidade e do hospital frente a antissépticos bucais. Os antissépticos avaliados foram: solução de Cloreto de Cetilpiridínio, Listerine $^{\circledR}$ e Neen ${ }^{\circledR}$. Na coleta de saliva para o isolamento do Staphylococcus spp. utilizou-se o swab de alginato de cálcio. O processamento microbiológico envolveu o crescimento, isolamento, identificação das cepas, determinação da DIM. Foi considerada DIM a maior diluição que inibiu completamente as cepas. A eficácia dos produtos foi avaliada por meio da análise de variância (ANOVA) bilateral com medidas repetidas, e pelo método de ajuste de Bonferroni nas comparações múltiplas, com um nível de significância $\alpha=0,05$. Totalizou-se 80 cepas de Staphylococcus spp. sendo 40 isoladas de pacientes da UTI e 40 de indivíduos da comunidade. Comparando os resultados é possível verificar que a solução de cloreto de cetilpiridínio apresentou melhores resultados em relação aos demais produtos, ou seja, 39 (97,5\%) das cepas hospitalares DIM 1:128 e da comunidade 37 (92,5\%) DIM 1:64. Para Neen ${ }^{\circledR}$ nos dois grupos a DIM foi de 1:2 e 1:4. Listerine ${ }^{\mathbb{B}}$ apresentou o pior resultado em termos da DIM, sendo que $65 \%$ das cepas da comunidade e 10\% hospitalar não foram inibidas na diluição 1:2.

Unitermos: Saúde bucal. Staphylococcus spp. Antissépticos bucais. Higiene bucal.

\footnotetext{
*Correspondence: D. Andrade. Faculdade de enfermagem, Universidade de São Paulo -Ribeirão Preto, Av. Bandeirantes 3.900, Monte Alegre, 14.040.902

- Ribeirão Preto-SP, Brazil. E-mail: dandrade@eerp.usp.br
} 


\section{INTRODUCTION}

Research developed in the last decades has shown the clinical condition of the mouth as an important attribute in the context of individuals' comprehensive health. Literature associates oral health as a risk factor for many clinical, specially infectious, complications (Diaz et al., 2000; Machado et al., 2000; Nelson et al., 2005). Thus, oral health care does not target only beautiful and healthy teeth, it participates significantly in quality of life.

It is presumed that mouth contains approximately 550 to 600 species of bacteria, besides viruses and fungus. Among the bacteria, there are the Actinomyces israeli, Capnocytophaga spp., Eikenella corrodens, Staphylococcus spp., Streptococcus mitis (Machado et al., 2000; Nelson et al., 2005). It is worth highlighting that oral microbiota coexists harmonically with the host, that is, keeps a microbiological homeostasis, commensalism, but for many factors can become pathogenic.

Although Staphylococcus spp., particularly, is part of individuals' normal microbiota, in determinate conditions it can cause infections, very frequent in hospitals (Diaz et al., 2000; Cavalcanti et al., 2005; Andrade, Leopoldo, Haas, 2006).

Researchers highlight that patients hospitalized in Intensive Care Units (ICU) are more vulnerable to develop infections deriving from oral microbiota or dental plaque biofilm (Bauer et al., 2002; Babcok et al., 2004; Brennan et al., 2004; Gusmão, Dourado, Fiaccone, 2004; Cavalcanti et al., 2005; Safdar, Crnich, Maki, 2005; Andrade, Leopoldo, Haas, 2006).

In addition, it is opportune to highlight the concept of dental plaque biofilm as the disposal of microorganisms in many layers, forming microbial communities highly resistant to phagocytes and antibiotics (Costerton, Stewart, Greenberg, 1999). If the bacterial plaque or the biofilm are not regularly removed by hygienization, they can cause caries and periodontal problems, such as gingivitis, among others.

Considerations concerning the oropharynx microbiota of critical patients in the ICU and the formation of the biofilm in the endotracheal tube have triggered questions worth researching. Currently, the use of antiseptic mouthwashes deserves attention, as their action reduce the microbial charge.

Besides using chemical products to fight microorganisms, it is necessary to know their efficacy against them, sometimes in hospitals, others in the community. Thus, this study aimed to assess susceptibility of Staphylococcus spp., isolated in the saliva of adult individuals from the community and hospitalized patients, to antiseptic mouthwashes.

\section{MATERIALS AND METHODS}

Experimental (laboratory) study with Staphylococcus spp. strains isolated from the saliva of individuals from the community and patients hospitalized in the Intensive Care Unit (ICU) with orotracheal tubes and subject to mechanical ventilation. The following antiseptic mouthwashes were assessed:

Cetylpyridinium Chloride (CPC) - solution prepared in the pharmacy of the hospital under study. Each milliliter of the solution contains $0.25 \%$ Cetylpyridinium Chloride, 0.2625 saccharin, $0.525 \mathrm{~mL}$ of water soluble mint extract, sicovit yellow CI 15-985 and distilled water q.s.p.

Listerine ${ }^{\circledR}$, produced by "Pfizer Consumer Healthcare's", its chemical composition contains essential oils, thymol, menthol or eucalyptol and methyl salicylate; water and alcohol $26.9 \%$ and $\mathrm{pH}$ 5.0. Producer recommends rinsing for 30 seconds with $20 \mathrm{~mL}$ of Listerine ${ }^{\circledR}$ after each brushing and dental floss use. It should not be diluted and is not recommended for children under 12 years old.

Neen ${ }^{\circledR}$, natural product produced by Floresça Indústria e Comércio de Cosméticos Ltda/SATTIVA-Goiânia$G O$. It is composed of $2 \%$ propolis tincture, $2 \%$ licorice extract, $0.1 \%$ eucalyptus oil, $0.1 \%$ mint oil and $1 \%$ neem (Azadirachta indica) tincture.

Determination of the Maximum Inhibitory Dilution (MID) of the antiseptic mouthwashes as to Staphylococcus spp., in the community and in hospital patients, was carried out in 96-well microtitration plates (microtit plates). Mouthwashes were subject to serial double dilution of 1:2, 1:4, 1:8, 1:16 until 1:1024 in $20 \mathrm{ml}$ test tubes.

These dilutions were poured into Petri plates $(20 x 100 \mathrm{~mm})$ with Mueller Hinton Broth (Difco $\left.{ }^{\circledR}\right)$ media and antiseptic, double concentration (2n). Afterwards, using a mutichannel pipette ( 8 channels), $100,0 \mu \mathrm{L}$ were distributed in each well of the microtit plates, starting from column $10(1: 1024)$ to column $1(1: 2)$. Using the mutichannel pipette, $5.0 \mu 1$ of standardized microbial suspension $(0.5 \mathrm{McF}$ arland scale) were injected in each well of the microtit plates, containing antiseptic diluted in culture media. Microtit plates were stored in a Tupperware plastic container and incubated at $35^{\circ} \mathrm{C}$ for 24 hours (Figure 1).

Reading was done with a stereomicroscope (Nikon, JP) under reflected light after inoculation of $2.0 \mu \mathrm{L}$ of triphenyltetrazolium chloride solution (TTC-Merck ${ }^{\circledR}$ ) at $200 \mathrm{mg}$ concentration in each well of the plate and incubation at $35{ }^{\circ} \mathrm{C}$ for approximately 30 minutes, to indicate the viability of the microorganisms (reddish color).

Dilution that caused complete inhibition of the microbial development was considered the Maximum Inhibitory Dilution. Figure 1 describes the MID phases. The 


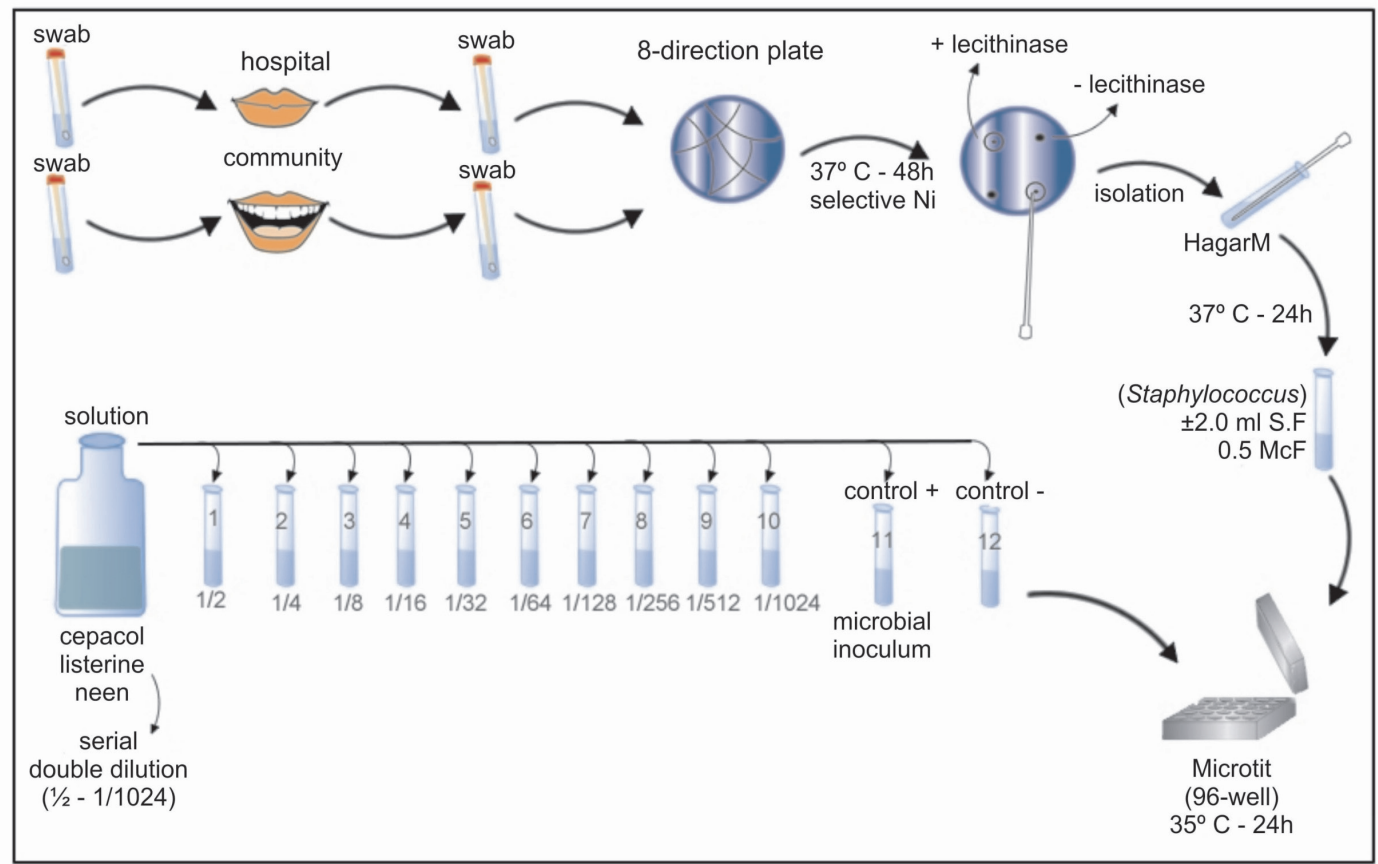

FIGURE 1 - Flow chart of antiseptic mouthwashes MID.

study was approved by the Research Ethics Committee.

For statistical analysis of the results, MID original values were subject to a logarithmic transformation, aiming to reduce the variability of this indicator. Thus, two-factors analysis of variance (ANOVA) with repeated measures was used:

-intra-subjects: antiseptic mouthwashes - cetylpyridinium chloride (CPC), Listerine ${ }^{\circledR}(\mathrm{L})$ and $\operatorname{Neen}^{\circledR}(\mathrm{N})$

-inter-subjects: origin of strains, from $\operatorname{Hospital}(\mathrm{H})$ and from the Community $(\mathrm{C})$.

The Statistical Package for the Social Sciences (SPSS), version 15.0, was used for all analyses, considering level of significance $\alpha=0.05$. For analysis of multiple comparisons, Bonferroni's adjustment method was used.

\section{RESULTS}

In total, 80 strains were analyzed, 40 isolated in the saliva of patients hospitalized in the ICU and 40 in individuals from the community.

Regarding the species, $75.8 \%$ of $S$. aureus was identified in the saliva of hospitalized patients and $24.4 \%$ in individuals from the community.

Tables I, II and III show the distribution of the Maximum Inhibitory Dilution of the analyzed antiseptic mouthwashes (CPC, Listerine ${ }^{\circledR}$, and Neen ${ }^{\circledR}$ ).

Table IV presents the mean and standard deviation for MID values in logarithmic scale (natural logarithm), clearly indicating the superiority of the cetylpyridinium chloride solution, always with higher MIDs for hospital strains in the analyzed products. In fact, a two-factor repeated ANOVA measure (Table V) permits to identify that, for an 0.05 level of significance, the origin of the strains is statistically significant for each of the products (intersubject factor), except for listerine.

The cetylpyridinium chloride solution was the only one to show inhibitory dilution in the interval from 1:32 to 1:4096, and the highest number of strains inhibited ranged from 1:128 to $1: 1024$. Besides that, for each treatment, MID values are higher for hospital strains, being also considered statistically significant the difference for all three treatments. The statistical analyses show that there is no doubt about CPC efficacy in the two groups of strains (hospital and community).

Regarding the other products assessed (Listerine ${ }^{\mathbb{B}}$ and $\mathrm{Neen}^{\circledR}$ ), inhibitory dilutions varied from 1:2 to $1: 64$ in the two groups (hospital and community). The antiseptic mouthwash Listerine ${ }^{\circledR}$ presented the worst result as to MID, as it did not have inhibitory action at any dilution in 26 community strains and the same result was shown in 4 hospital strains.

\section{DISCUSSION AND CONCLUSION}

According to Tables I and III, the cetylpyridinium chloride solution presented better Maximum Inhibitory Dilution (MID) results. It is highlighted that the solution is produced in the pharmacy of the hospital under study and 
TABLE I - Numbers, Percentages and Accumulated frequency F(a) of the MID of CPC mouthwash as to Staphylococcus spp. isolated in the saliva of individuals from the community and hospital. Ribeirão Preto. 2006

\begin{tabular}{|c|c|c|c|c|c|c|c|c|}
\hline \multirow[t]{4}{*}{ MID (CPC) } & \multicolumn{8}{|c|}{ Staphylococcus spp. } \\
\hline & \multicolumn{4}{|c|}{ Community } & \multicolumn{4}{|c|}{ Hospital } \\
\hline & \multicolumn{4}{|c|}{$\mathrm{F}(\mathrm{a})$} & & & \multicolumn{2}{|c|}{$\mathrm{F}(\mathrm{a})$} \\
\hline & $\mathrm{N}$ & $\%$ & $\mathrm{~N}$ & $\%$ & $\mathrm{~N}$ & $\%$ & $\mathrm{~N}$ & $\%$ \\
\hline $1 / 4096$ & & & & & 1 & 2.5 & 1 & 2.5 \\
\hline $1 / 2048$ & & & & & 5 & 12.5 & 6 & 15.0 \\
\hline $1 / 1024$ & 1 & 2.5 & 1 & 2.5 & 4 & 10.0 & 10 & 25.0 \\
\hline $1 / 512$ & 4 & 10.0 & 5 & 12.5 & 12 & 30.0 & 22 & 55.0 \\
\hline $1 / 256$ & 22 & 55.0 & 27 & 67.5 & 15 & 37.5 & 37 & 92.5 \\
\hline $1 / 128$ & 4 & 10.0 & 31 & 77.5 & 2 & 5.0 & 39 & 97.5 \\
\hline $1 / 64$ & 6 & 15.0 & 37 & 92.5 & 1 & 2.5 & 40 & 100.0 \\
\hline $1 / 32$ & 3 & 7.5 & 40 & 100.0 & & & & \\
\hline Total & 40 & 100.0 & & & 40 & 100.0 & & \\
\hline
\end{tabular}

TABLE II - Numbers, Percentages and Accumulated frequency F(a) of the MID of Listerine ${ }^{\circledR}$ as to Staphylococcus spp. isolated in the saliva of individuals from the community and hospital. Ribeirão Preto. 2006

\begin{tabular}{|c|c|c|c|c|c|c|c|c|}
\hline \multirow{4}{*}{$\begin{array}{l}\text { MID } \\
\text { Listerine }^{\circledR}\end{array}$} & \multicolumn{8}{|c|}{ Staphylococcus spp. } \\
\hline & \multicolumn{4}{|c|}{ Community } & \multicolumn{4}{|c|}{ Hospital } \\
\hline & \multicolumn{4}{|c|}{$\mathrm{F}(\mathrm{a})$} & & & \multicolumn{2}{|c|}{$\mathrm{F}(\mathrm{a})$} \\
\hline & $\mathrm{N}$ & $\%$ & $\mathrm{~N}$ & $\%$ & $\mathrm{~N}$ & $\%$ & $\mathrm{~N}$ & $\%$ \\
\hline $1 / 512$ & 1 & 2.5 & 1 & 2.5 & & & & \\
\hline $1 / 16$ & 1 & 2.5 & 2 & 5.0 & 1 & 2.5 & 1 & 2.5 \\
\hline $1 / 8$ & 1 & 2.5 & 3 & 7.5 & 1 & 2.5 & 2 & 5.0 \\
\hline $1 / 4$ & 5 & 12.5 & 8 & 20.0 & 4 & 10.0 & 6 & 15.0 \\
\hline $1 / 2$ & 6 & 15.0 & 14 & 35.0 & 30 & 75.0 & 36 & 90.0 \\
\hline No action & 26 & 65.0 & & & 4 & 10.0 & & \\
\hline Total & 40 & 100.0 & & & 40 & 100.0 & & \\
\hline
\end{tabular}

According to data from table 2, Listerine ${ }^{\circledR}$ inhibited only 14 (35\%) of Staphylococcus spp. community strains at a dilution 1:2, against $36(90 \%)$ hospital strains at the same dilution.

TABLE III - Numbers, Percentages and Accumulated frequency F(a) of the MID of Neen ${ }^{\circledR}(\mathrm{N})$ as to Staphylococcus spp. isolated in the saliva of individuals from the community and hospital. Ribeirão Preto. 2006

\begin{tabular}{|c|c|c|c|c|c|c|c|c|}
\hline \multirow[t]{3}{*}{ MID Neen $^{\circledR}$} & \multicolumn{8}{|c|}{ Staphylococcus spp. } \\
\hline & & & $\mathrm{F}(\mathrm{a})$ & & & & $F(a)$ & \\
\hline & $\mathrm{N}$ & $\%$ & $\mathrm{~N}$ & $\%$ & $\mathrm{~N}$ & $\%$ & $\mathrm{~N}$ & $\%$ \\
\hline $1 / 64$ & & & & & 1 & 2,5 & 1 & 2.5 \\
\hline $1 / 32$ & 1 & 2.5 & 1 & 2.5 & & & & \\
\hline $1 / 16$ & 3 & 7.5 & 4 & 10.0 & 3 & 7.5 & 4 & 10.0 \\
\hline $1 / 8$ & 9 & 22.5 & 13 & 32.5 & 24 & 60.0 & 28 & 70.0 \\
\hline $1 / 4$ & 26 & 65.0 & 39 & 97.5 & 12 & 30.0 & & \\
\hline $1 / 2$ & 1 & 2.5 & & & & & & \\
\hline Total & 40 & 100.0 & & & 40 & 100.0 & & \\
\hline
\end{tabular}

The antiseptic mouthwashe $\mathrm{Neen}^{\circledR}$, at dilution 1:4, inhibited 39 (97.5\%) of community strains and, at dilution 1:8, inhibited 28 $(70 \%)$ hospital strains. 
TABLE IV - Position measures and logarithm variability of the MID of the three antiseptic mouthwahses regarding community and hospital strains

\begin{tabular}{lccc}
\hline & MID & - & $\rho$ \\
\hline CPC & Hospitalized & 6.1517 & 0.89054 \\
& Community & 5.2159 & 0.81544 \\
& Total & 5.6838 & 0.97028 \\
& & & \\
Listerine & Hospitalized & 0.7798 & 0.50100 \\
& Community & 0.5545 & 1.14489 \\
& Total & 0.6672 & 0.88535 \\
& & & \\
Neen & Hospitalized & 1.9755 & 0.53346 \\
& Community & 1.6809 & 0.54119 \\
& Total & 1.8282 & 0.55412 \\
\hline
\end{tabular}

Legend: -x-mean $\rho$ - standard deviation

has been used in patients, including the ones hospitalized in the ICU.

In Brazil, there is lack of literature on the theme, as few studies assessed the antimicrobial action of antiseptic mouthwashes. Thus, it is important to mention Monfrin and Ribeiro's (2000) study, who evaluated the efficacy of antiseptic mouthwashes (Kolynos, produced by Kolynos do Brasil; Bucal-B, produced by Gillette do Brasil; Cepacol, produced by Hoechst Marion Roussel; Periogard, produced by Colgate-Palmolive; Flogbucal, produced by Asta Médica; Malvatricin, produced by Laboratório Daudt Oliveira Ltda.; Fluordent, produced by Johnson \& Johnson; Wash, produced by Abbott Laboratórios do Brasil Ltda.; Plax, produced by Pfizer do Brasil (currently Colgate-Palmolive) and Listerine from Johnson \& Johnson in the reduction of saliva microbiota. Samples from the saliva of 50 individuals aged between 19 and 54 years were selected. After cultivation of the sample microorganisms, the ten different antiseptic mouthwashes were inoculated in three dosages $(10 \mu 1,20 \mu 1,25 \mu 1)$. Results revealed that Periogard was more effective in the reduction of the saliva microbiota, and that Listerine and Flogbucal were ineffective in relation to antimicrobial activity.

Other researchers, such as Witt et al. (2005) and Tirapelli and Ito (2003), showed that the use of cetylpyridinium chloride reduces the number of microorganisms in the mouth, specially Streptococcus. In addition, it has also been evidenced that chlorhexidine gluconate use in mouthwashes significantly reduces the population of aerobic and anaerobic bacteria in the mouth (Charles et al., 2005).

Carvalho (1989) correlated the index of plaque with brushing, with sodium fluoride and cetylpyridinium chloride mouth rinse. It was concluded that brushing associated with cetylpyridinium chloride mouth rinse is a promising hygiene behavior regarding the control of the index of dental plaque biofilm.

Pinheiro (1991) assessed, in vitro, the effect of cetylpyridinium chloride and sodium fluoride in the fermentation and synthesis of insoluble extracellular polysaccharides of dental plaque. The 1:10 dilution of this substance inhibited $96 \%$ of the fermentation acids and $100 \%$ of the synthesis of insoluble polysaccharides. Considering that the dilution normally used in mouth rinse is $1: 2$, it was concluded that this is a highly effective collutory against dental plaque microorganisms.

Garib et al. (1995) evaluated the efficacy of mouth rinse with $0.12 \%$ chlorhexidine solution and cetylpyridinium chloride in the reduction of dental plaque and gingivitis. The obtained results allowed for the following conclusions: a) mouth washing led to a statistically significant reduction of dental plaque and gingival bleeding indexes in the three experimental groups. Nevertheless, there was no statistically significant difference among the groups; b) isolatedly, cetylpyridinium chloride led to a reduction of $23.6 \%$ in dental plaque and $55.9 \%$ in gingival bleeding indexes. When associated to chlorhexidine, it led to a $52.2 \%$ reduction in the index of plaque and $62.9 \%$ in the index of bleeding.

Table V - Analysis of variance with repeated measures of MID for the three antiseptic mouthwashes (CPC, L and N) in two groups of strains, community and hospital $(\mathrm{C}, \mathrm{H})$

\begin{tabular}{lcccc}
\hline Mouthwashes/ strains & Differences among means & $(\mathrm{p})$ & \multicolumn{2}{c}{$95 \%$ confidence interval } \\
\hline $\mathrm{CPC} /(\mathrm{H}$ and $\mathrm{C})$ & 0.936 & $<0.001$ & 0.556 & 1.316 \\
$\mathrm{~L} /(\mathrm{H}$ and C) & 0.225 & 0.258 & -0.168 & 0.619 \\
$\mathrm{~N} /(\mathrm{H}$ and $\mathrm{C})$ & $0.295^{*}$ & 0.016 & 0.055 & 0.534 \\
$\mathrm{CPC} / \mathrm{L}$ & 5.017 & $<0.001$ & 4.697 & 5.336 \\
$\mathrm{CPC} / \mathrm{N}$ & 3.856 & $<0.001$ & 3.599 & 4.112 \\
$\mathrm{~L} / \mathrm{N}$ & $-1.161^{*}$ & $<0.001$ & -1.375 & -0.947 \\
\hline
\end{tabular}


In general, the following products are routinely used in oral hygiene and in the control of dental plaque biofilm: Chlorhexidine (0.12\%); Plax; Periogard; Noplak; Cetylpyridinium Chloride - cepacol; Triclosan; Malvatricin; Sodium Bicarbonate; Zinc chloride; Listerine; among others. The total amount of plaque present on the teeth surface is directly influenced by individual oral hygiene, and shows high inter-individual variation. During severe or acute phases of gingivitis, or when patients have a deficient plaque control, an associated chemical should be temporarily used in the control of dental plaque. These solutions should have in vitro antimicrobial action, and should not present irreversible adverse effects (APECIH, 2000).

In dental practice, intra-mouth antisepsis should be done with a substance compatible to the mouth mucosa and, thus, only water-based solutions are indicated. Another important issue is the toxicity of the active principles, since they can be ingested when used and absorbed by mouth mucosa (Seabra et al., 2005). Aspects like toxicity, tolerance, antimicrobial action and cost justify the development of research to search for alternative options, such as the present study. Thus, the solution Neen ${ }^{\circledR}$ was evaluated, a natural product with almost nonexistent toxicity and low cost, if compared to the other products, including chlorhexidine.

The product Listerine ${ }^{\circledR}$, with essential oils, contains thymol, menthol, eucalyptol and methyl salicylate. It is available with $26.9 \%$ alcohol vehicle and $\mathrm{pH} 5$, which justify adverse effects, such as burning sensation and taste. According to the producer's label, it is recommended to be used in 30-secods rinses, twice a day. Recently, zinc chloride has been added to the product since, according to producer, it interferes in the formation of calcium phosphate crystals, and in the mineralization of the dental plaque, decreasing tartar formation.

The comparison of the results of the present study showed that mean and standard deviation for MID values in logarithmic scale indicated the superiority of the cetylpyridinium chloride solution (CPC), which always had higher MIDs in hospital strains. Cetylpyridinium chloride, at 1:64 dilution, inhibited $37(92.5 \%)$ of community strains and $39(97.5 \%)$ of ICU strains. Listerine ${ }^{\circledR}$, at 1:2 dilution, inhibited $14(35 \%)$ of community strains and $36(90 \%)$ of ICU strains. Neen ${ }^{\circledR}$ at 1:4 dilution inhibited $39(97.5 \%)$ of community strains, and 28 (70\%) of ICU strains.

\section{ACKNOWLEDGEMENTS}

This study was supported by FAPESP - The State of São Paulo Research Foundation.

\section{REFERENCES}

ANDRADE, D.; LEOPOLDO, V.C.; HAAS, V.J. Ocorrência de bactérias multiresistentes em um Centro de Terapia Intensiva de hospital brasileiro de emergências. Rev. Bras. Ter. Intensiva, v.18, n.1, p.31-37, 2006.

APECIH. Associação Paulista de Estudos e Controle de Inecção Hospitalar. Controle de infecção na prática odontológica. São Paulo, 2000. p.25-36

BABCOCK, H.M.; ZACK, J.E.; GARRISON, T.; TROVILLION, E.; JONES, M.; FRASER, V.J.; KOLLEF, M.H. An educational intervention to reduce ventilatorassociated pneumonia in an integrated health system: a comparison of effects. Chest, v.125, n.6, p.2224-2231, 2004.

BAUER, T.T.; TORRES, A.; FERRER, R.; HEYER, C.M.; SCHULTZE-WERNINGHAUS, G.; RASCHE K. Biofilm formation in endotracheal tubes. Association between pneumonia and the persistence of pathogens. Monaldi Arch. Chest. Dis., v.57, n.1, p.84-87, 2002.

BERGMANS, D.C.J.J.; BONTEN, M.J.M.; GAILLARD, C.A.; PALING, J.C.; VANDERGEEST, S.; VANTIEL, F.H.; BEYSENS, A.J.; LEEUW, P.W.; STOBBERINGH, E.E. Prevention of ventilator-associated pneumonia by bucal decontamination. A prospective, randomized, double-blind, placebo-controlled study. Am. J. Respir. Crit. Care Med., v.164, p.382-388, 2001.

BRENNAN, M.T.; BAHRANI-MOUGEOT, F.; FOX, P.C.; KENNEDY, T.P.; HOPKINS, S.; BOUCHER, R.C.; LOCKHART, P.B. The role of bucal microbial colonization in ventilator-associated pneumonia. Bucal Surg. Bucal Med. Bucal Pathol. Bucal. Radiol. Endod., v.98, n.6, p.665-672, 2004.

CARVALHO, L.S. Estudo em pacientes portadores de aparelho ortodôntico correlacionando os índices de placa com á escovação dental e bochechos com de fluoreto de sódio e cloreto de cetilpiridineo. São Paulo, 1989. 107 p. [Tese doutorado. Faculdade de Odontologia de São Paulo. Universidade de São Paulo].

CAVALCANTI, S.M.M.; FRANÇA, E.R.; CABRAL, C.; VILELA M.A.; MONTENEGRO F.; MENEZES D.; MEDEURIS A.C. Prevalence of Staphylococcus aureus introduced into intensive care units of a University Hospital. Braz. J. Infect. Dis., v.9, n.1, p.56-63, 2005. 
CHARLES, C.H.; SHARMA, N.C.; GALUSTIANS, H.J.; QAQISH, J.I.; MCGUIRE, J.A.; VINCENT, J.W. Comparative efficacy of an antiseptic mouthrinse and an antiplaque/antigingivitis dentifrice: a six-month clinical trial. J. Am. Dent. Assoc., v.132, n.5, p. 670-675, 2001.

COSTERTON, J.W.; STEWART, P.S.; GREENBERG, E.P. Bacterial biofilm: a common cause of persistent infections. Science, v.284, n.5418, p.1318-1322, 1999.

DIAZ, R.L.; JUNCO, A.; MARRERO, M.L; ORTIZ, C.L. Staphylococcus e infeccíon nosocomial. Rev. Cub. Epidemiol. Mol., v.38, n.1, p.24-28, 2000.

GARIB, D.G.; UNGARO, A.E.; HENRIQUES, J.F.C.; BASTOS, J.R.M. Efeito do uso do gluconato de clorexidina e do cloreto de cetilpiridínio, em bochechos, como meio complementar da higiene bucal em pacientes sob tratamento ortodôntico. Ortodontia, v.30, n.2, p.22-30, 1995.

GUSMÃO, M.E.N.; DOURADO, I.; FIACCONE, R.L. Nosocomial pneumonia in the intensive care unit of a Brazilian university hospital: an analysis of the time span from admission to disease onset. AJIC, v.32, n.4, p.209214, 2004.

MACHADO, W.A.S.; SARDENBERG, E.M.S.; KAHAN, S.; ALVES, J. A clorexidina no controle de placa em pacientes internados:estudo piloto. Rev. Bras. Odontol., v.59, n.6, p.390-392, 2000.
MONFRIN, R.C.P.; RIBEIRO, M.C. Avaliação in vitro de antissépticos bucais sobre a microbiota da saliva. Rev. Assoc. Paul. Cir. Dent., v.54, n.4, p.400-407, 2000.

NELSON, S.; NECHVATAL, N.; WEBER, J.; CANION, S. Dental caries and ear infections in preschool-aged children. Oral Health Prev. Dent., v.3, n.3, p.165-171, 2005.

PINHEIRO, C.E. Efeito da associaçäo cloreto de cetilpiridíniofluoreto de sódio na fermentaçäo e na síntese de polissacarídeos extracelulares insolúveis da placa dentária “in vitro”. Rev. Bras. Odontol., v.48, n.1, p.18-20, 1991.

SAFDAR, N.; CRNICH, C.J.; MAKI, D.G. The pathogenesis of ventilator-associated pneumonia: its relevance to developing effective strategies for prevention. Respir. Care, v.50, n.6, p.725-739, 2005.

SEABRA, E.J.G.; LIMA, I.P.C.; BARBOSA, S.V. Antimicrobial activity "in vitro" of calcium hydroxide and tergentol on different concentrations in bucal bactéria. Acta Cir. Bras.,v.20, suppl.1, p.12-18, 2005.

TIRAPELLI, C.; ITO, I.Y. Avaliação do efeito de quatro antissépticos orais no nível de estreptococos do grupo mutans na saliva in vivo. Rev. ABO Nac., v.11, n.1, p.4752, 2003.

WITT, J.; RAMJI, N.; GIBB, R.; DUNAVENT, J.; FLOOD, J.; BARNES, J. Antibacterial and antiplaque effects of a novel, alcohol-free oral rinse with cetylpyridinium chloride. $J$. Contemp. Dent. Pract., v.15, n.1, p.1-9, 2005.

Received for publication on $5^{\text {th }}$ November 2007 Accepted for publication on $13^{\text {th }}$ January 2009 